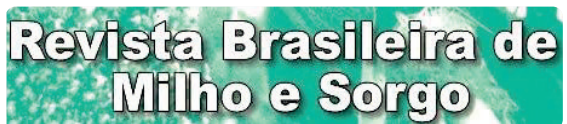

Brazilian Journal of Maize and Sorghum

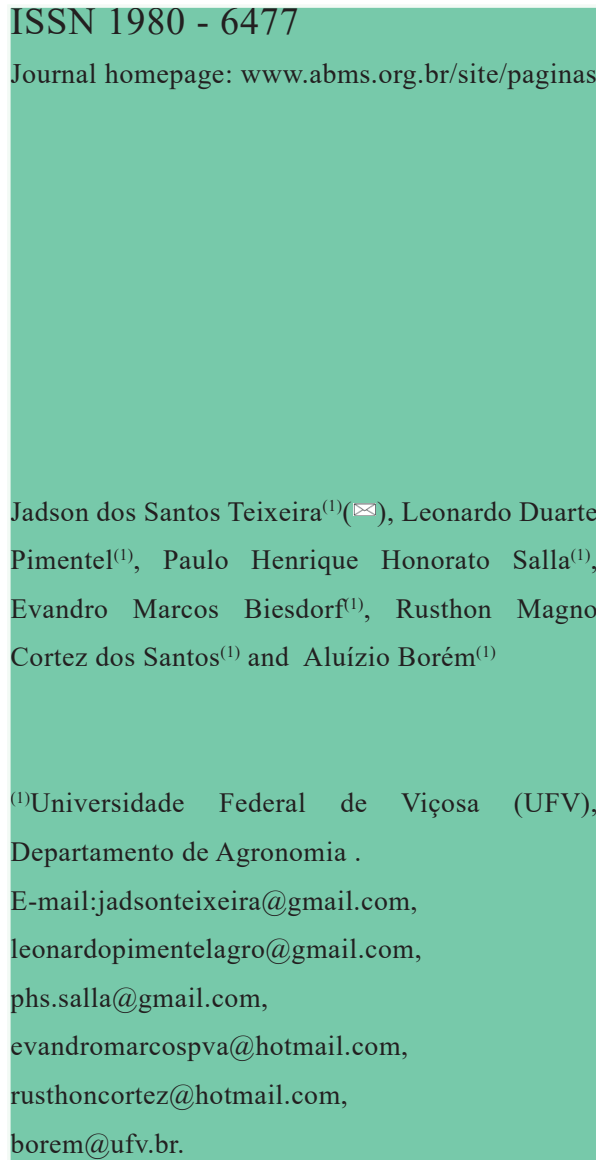

Corresponding author

How to cite

TEIXEIRA, J. S.; PIMENTEL, L. D.; SALLA, P H. H.; BIESDORF, E. M.; SANTOS, R. M. C. BORÉM, A. Characterization of broom sorghum accessions using morpho-agronomic descriptors. Revista Brasileira de Milho e Sorgo, v. 19, e1166, 2020

\section{CHARACTERIZATION OF BROOM SORGHUM ACCESSIONS USING MORPHO-AGRONOMIC DESCRIPTORS}

\begin{abstract}
The straw broom production is a traditional and very old activity among small farmers in Brazil. Much of the straw broom production is manufactured with native species, which in turn are in the process of being extinct. The objective of this work was to evaluate the genetic diversity and to characterize one sample of broom sorghum germplasm constituted of 66 accessions. The experiment was carried out in Viçosa, MG, in a randomized block design with two replicates, being each plot composed of one $5 \mathrm{~m}$ row, with $0.7 \mathrm{~m}$ spacing, where eight morpho-agronomic traits were evaluated. The studied accessions presented genetic variability for most of the traits. The accessions 2, 7 and 16 presented the lowest plant heights. Regarding stem diameter, accessions 7,11 , and 13 presented the highest values. As to the number of days from emergence to flowering, the accessions 42,65 , and 66 were the earliest ones. Based on the evaluations carried out, it can be concluded that accessions $2,7,11,13,42,65$, and 66 are the most promising for new studies and launches.
\end{abstract}

Keywords: Variability, Sorghum bicolor, Germplasm, Diversity.

\section{CARACTERIZAÇÃO DE ACESSOS DE SORGO- VASSOURA UTILIZANDO DESCRITORES MORFO- AGRONÔMICOS}

Resumo - A produção de vassoura de palha é uma atividade tradicional e muito antiga entre pequenos produtores no Brasil. Boa parte da produção de vassoura de palha é feita com espécies nativas que, por sua vez, encontram-se em processo de extinção. Objetivou-se com esse trabalho avaliar a diversidade genética e caracterizar uma amostra do germoplasma de sorgo-vassoura constituído de 66 acessos. O experimento foi realizado em Viçosa, MG, em delineamento casualizado em blocos, com duas repetições, sendo cada parcela constituída por 1 fileira com espaçamento de 5,0 x 0,7 m, nas quais foram avaliadas oito características morfo-agronômicas. Os acessos estudados apresentaram variabilidade genética para a maioria das características. Os acessos 2, 7 e 16 apresentaram as menores alturas de plantas. Para diâmetro do colmo, os acessos 7, 11 e 13 apresentaram os maiores diâmetros. Para número de dias da emergência até o florescimento, os acessos 42, 65 e 66 foram os mais precoces. Com base nas avaliações, conclui-se que os acessos 2, 7, 11, 13, 42, 65 e 66 são os mais promissores para novos estudos e lançamentos.

Palavras-chave: Variabilidade, Sorghum bicolor, Banco de germoplasma, Diversidade. 
Sorghum [Sorghum bicolor (L.) Moench] is the fifth most grown cereal crop in the world, after wheat, rice, maize and barley. In addition to being used for human consumption and animal feed, the sorghum can be used as raw material for the production of ethanol, sugar, alcoholic beverages, glue and paints, and, with the panicles, brooms can be produced (Ribas, 2008).

Basically, there are five types of sorghum: sweet, grain, forage, biomass and broom. The broom sorghum is grown from north to south of Brazil, though still with no significant economic expression in the national scenario, mainly when compared with other crops. It is of great importance in the domestic market, since it is grown by small farmers and its crop has strongly contributed to complement their family income (Foltran et al., 2016).

Commercial broom sorghum cultivars present medium size, with height around 2.10 $\mathrm{m}$, panicle length over $50 \mathrm{~cm}$, and flowering between 70 and 75 days after sowing, depending on the region, though early cycle cultivars are preferred by farmers.

In the 1930s, great part of the broom production in Brazil was derived from broom sorghum, with most of the straw used in the production being imported from other countries, mainly from Argentina, Italy and Uruguay. Although the production of broom sorghum was a traditional practice in small rural properties in Brazil, mainly in the south and southeast regions, the production was not sufficient to meet the domestic demand. The increased demand and the manufacture of sorghum broom advanced until the synthetic fibers appeared and the brooms made of those fibers gained access to the market, together with the piassava brooms. Consequently, the sorghum brooms lost space in the market (Foltran, 2012).

In the cerrado, for example, the plant that is most used as raw material is a small palm tree species known as coqueirinho-do-cerrado (Syagrus sp.). In the northeast of Brazil, the Ouricury palm [Syagrus coronata (Mart.) Becc.] is used for straw broom production. However, the availability of the fiber from those species is being quickly reduced, as a result of intensive collection, very slow regrowth, and agricultural expansion in their habitat. As a consequence, the small palm species is in fast extinction process, which may reduce that source of income for family farmers (Farias et al., 2000; Favarato et al., 2011).

In this context, the broom sorghum can be an alternative to the use of native material. The sorghum enables great yield of straw per hectare, around $900 \mathrm{~kg}$ or about 1,500 brooms, does not require specialized workforce, and the raw material can be obtained within few months and at low cost. Additionally, the sorghum broom is a green technology product, with prices that have been increasing for years, which shows the tendency towards the increase in its consumption (Foltran \& Tavares, 2016). In view of that, the objective of this work was to assess the genetic diversity and correlate the quantitative traits of 66 broom sorghum accessions, as well as to select 
those that present potential for commercial crop.

\section{Material and Methods}

The experiment was conducted from January to May 2017, on the experimental field Diogo Alves de Mello, owned by the Federal University of Viçosa (UFV) and located in the municipality of Viçosa, MG, with geographic coordinates of $20^{\circ} 46^{\prime} \mathrm{S}$ latitude and $45^{\circ} 52^{\prime} \mathrm{W}$ longitude, at an altitude of approximately $650 \mathrm{~m}$. According to the Köeppen-Geiger classification system, the climate in the region is humid subtropical with dry winter and hot summer. The average annual temperature is $21^{\circ} \mathrm{C}$, with average annual precipitation of $1,200 \mathrm{~mm}$. The local soil is classified as Red-Yellow Argisol (May et al., 2013).

A randomized block design was used, with 2 replicates. The treatments were arranged in plots, each of them consisting of a single 5-meter row, with $0.7 \mathrm{~m}$ spacing between rows. An amount of 10 seeds were sown per linear meter, totalling a population of 143 thousand plants per hectare. In each plot, the central 4-meter area was assessed, with $0.5 \mathrm{~m}$ at each end of the plot being considered as border.

The soil preparation was carried out according to recommendations for the crop. The seeds were evenly distributed at a depth of approximately 3 to $4 \mathrm{~cm}$, being covered right after. During the experiment period, two manual weeding operations were performed at 15 and 30 days after germination.

For all accessions, the following traits were assessed: plant height $(\mathrm{PH})$, at physiological maturity, considering the distance in meters (m) from the soil level to the apex of the panicle; stem diameter (SD), measured in millimeters $(\mathrm{mm})$, between 15 and $20 \mathrm{~cm}$ from the soil surface, on the central region of the second internode, at physiological maturity of the plants; length of the third leaf blade / lamina (LLB) in centimeters $(\mathrm{cm})$, as from the flag leaf, determined at physiological maturity of the crop; width of the third leaf blade / lamina (WLB) in centimeters (cm); number of leaves (NL), assessed at physiological maturity, upon counting of the number of photosynthetically active leaves (unit); panicle length (PL), from the base of the panicle until the apex $(\mathrm{cm})$; length of the secondary branching (LSB), as from the middle-third of the panicle $(\mathrm{cm})$; and number of days from emergence to flowering (NDF), assessed when $50 \%$ of the plants had the panicle emitting pollen.

The results were submitted to analysis of variance and the means were compared through Scott-Knott test at $1 \%$ probability. The RBIO software (Bhering, 2017) was used in the statistical analysis, including calculations of genotypic and phenotypic variances, as well as coefficients of variation (CV) and correlations between the data. Evaluation of genetic diversity of the accessions was performed using the matrix of Mahalanobis in the Genes software (Cruz, 2017).

Revista Brasileira de Milho e Sorgo, v.19, e1166, 2020 DOI: https://doi.org/10.18512/rbms2020v19e1166 


\section{Results and Discussion}

The summary of the analyses of variance is presented in Table 1. According to the F-test, there were significant differences at $1 \%$ probability for the following traits: plant height $(\mathrm{PH})$; stem diameter (SD); length of third leaf blade (LLB); width of third leaf blade (WLB); number of leaves (NL); panicle length (PL); and number of days from emergence to flowering (NDF). In regard to the length of secondary branching (LSB), there was significant difference at 5\% probability, according to the F-test.

Among the accessions evaluated, the phenotypic and genetic variances presented low magnitude for most of the traits studied, with exception of length of third leaf blade, which presented values of 28.08 for phenotypic variance and 14.61 for genetic variance, and panicle length, which presented values of 18.9 for phenotypic variance and 11.5 for genetic variance, thus indicating that there is a high level of genetic variability among the accessions in regard to those traits.

For most of the traits evaluated, the coefficient of variation (CV) was considered of optimum experimental precision. Only the length of secondary branching presented $\mathrm{CV}$ of good experimental precision, according to Ferreira (2018). In accordance with the classification by Gomes (2009), the evaluated traits presented low and medium coefficients of variation.

Such results corroborate those found by Tardin et al. (2013), who obtained coefficients

Table 1. Variance components, coefficient of variation (CV) and means of traits evaluated in broom sorghum accessions.Viçosa, MG, Brazil.

\begin{tabular}{ccccc}
\hline Trait & Phenotypic Variance & Genotypic Variance & CV & Mean \\
& & & & \\
\hline PH & $0.07^{* *}$ & 0.05 & 5.19 & 3.91 \\
SD & $5.58^{* *}$ & 5.21 & 9.01 & 9.55 \\
LLB & $28.08^{* *}$ & 14.61 & 6.66 & 77.92 \\
WLB & $0.42^{* *}$ & 0.23 & 9.04 & 6.87 \\
NL & $0.27^{* *}$ & 0.16 & 4.74 & 10.18 \\
PL & $18.9^{* *}$ & 11.5 & 7.69 & 50.15 \\
LSB & $1.50^{*}$ & 0.58 & 13.81 & 9.82 \\
NDF & $6.85^{* *}$ & 6.85 & 2.42 & 63.09 \\
\hline
\end{tabular}

Plant height (PH, cm); stem diameter (SD, mm); length of third leaf blade (LLB, cm); width of third leaf blade (WLB, $\mathrm{cm}$ ); number of leaves (NL, unit); panicle length (PL, cm); length of secondary branching (LSB, cm); number of days from emergence to flowering (NDF, days). ** and * significant at $1 \%$ and $5 \%$ probability level, respectively, according to F-test. Phenotypic and genotypic variance, respectively. Coefficient of variation (CV \%). 
of variation of $1.24 \%$ for flowering and $8.05 \%$ for plant height, when assessing 49 grain sorghum hybrids grown under irrigation and water stress conditions. Oliveira (2015), when evaluating genetic divergence and correlation between characters of sweet sorghum genotypes in the region of Cáceres, MT, obtained coefficients of variation of $5.33 \%$ and $7.51 \%$ for number of leaves and stem diameter, respectively.

In respect to plant height, the accessions presented mean values of $3.91 \mathrm{~m}$, with three groups being formed based on the means obtained, thus indicating that there is variability among the accessions studied. The accessions that presented the lowest heights were 2, 7 and 16, with mean values of $3.07 \mathrm{~m}, 3.26 \mathrm{~m}$ and $3.19 \mathrm{~m}$, respectively (Table 2).

Plant height is an extremely important trait because it is directly correlated with the production of green matter and dry matter. In regard to the broom sorghum, plant height directly interferes with the harvesting process, considering that this process is carried out manually. Therefore, broom sorghum varieties with low to medium size are preferred. In this context, the accessions in the group present desirable heights for commercial crop.

Stem diameter presented mean value of 9.55 $\mathrm{mm}$ for the accessions evaluated. However, the accessions 7,11 and 13 presented higher means of $18.84 \mathrm{~mm}, 19.58 \mathrm{~mm}$ and $20.70 \mathrm{~mm}$, respectively. These results are similar to those found by Oliveira (2015) upon assessment of genetic divergence and correlation between characters of sweet sorghum genotypes, when a mean value of $18.59 \mathrm{~mm}$ was obtained for SD. For this trait, the accessions were divided into two groups, demonstrating variability among the accessions. Similarly, length of third leaf blade and width of third leaf blade enabled the formation of two groups.

The stem diameter trait is correlated with lodging and breakage. Consequently, plants with larger stem diameter are preferred in order to minimize production and quality losses due to lodging (Rabelo et al., 2012). The accessions 7,11 and 13 presented mean values of $19.70 \mathrm{~mm}$ for SD, which are superior to the mean values of the other accessions studied. These results were superior to those found by Perazzo et al. (2013), who obtained mean value of $15.92 \mathrm{~mm}$ for stem diameter, when studying agronomic features and rainwater use efficiency in sorghum cultivars in the semi-arid region.

With regard to the number of leaves, the accessions were divided into two groups, with an overall mean of 10.18 leaves. This result was superior to the ones found by Ferreira et al. (2012), who obtained mean value of 8.49 leaves for sorghum with double purpose and 7.27 for forage sorghum, when characterizing sorghum varieties submitted to different fertilizing treatments under no irrigation regime. Number of leaves is a trait that is correlated with the plant capacity to synthesize photoassimilates. Therefore, plants with higher number of leaves are preferred.

Panicle length is the most important trait for broom sorghum, since this characteristic is 
Table 2. Means of quantitative traits evaluated in broom sorghum accessions and Scott-Knott Test per variable.

\begin{tabular}{|c|c|c|c|c|c|c|c|c|}
\hline Accessions & $\begin{array}{l}\text { PH } \\
\text { (m) }\end{array}$ & $\begin{array}{c}\text { SD } \\
(\mathrm{mm})\end{array}$ & $\begin{array}{l}\text { LLB } \\
(\mathrm{cm})\end{array}$ & $\begin{array}{l}\text { WLB } \\
\text { (cm) }\end{array}$ & $\begin{array}{c}\text { NL } \\
\text { (unit) }\end{array}$ & $\begin{array}{l}\text { PL } \\
\text { (cm) }\end{array}$ & $\begin{array}{l}\text { LSB } \\
(\mathrm{cm})\end{array}$ & NDF (days) \\
\hline SV 01 & $3.96 \mathrm{c}$ & $8.96 \mathrm{a}$ & $77.00 \mathrm{a}$ & $6.49 \mathrm{a}$ & $9.66 \mathrm{a}$ & $47.49 \mathrm{a}$ & $8.49 \mathrm{a}$ & $65 \mathrm{~d}$ \\
\hline SV 02 & $3.07 \mathrm{a}$ & $9.14 \mathrm{a}$ & $81.00 \mathrm{~b}$ & $6.33 \mathrm{a}$ & $10.16 \mathrm{a}$ & $41.66 \mathrm{a}$ & $7.86 \mathrm{a}$ & $61 \mathrm{~b}$ \\
\hline SV 03 & $3.61 \mathrm{~b}$ & $8.96 \mathrm{a}$ & $78.99 \mathrm{~b}$ & $7.16 \mathrm{~b}$ & $8.99 \mathrm{a}$ & $65.33 \mathrm{a}$ & $11.33 \mathrm{~b}$ & $61 \mathrm{~b}$ \\
\hline SV 04 & $3.57 \mathrm{~b}$ & $8.16 \mathrm{a}$ & $83.33 \mathrm{~b}$ & $6.58 \mathrm{a}$ & $10.00 \mathrm{a}$ & $53.83 \mathrm{a}$ & $10.83 \mathrm{~b}$ & $61 \mathrm{~b}$ \\
\hline SV 05 & $3.98 \mathrm{c}$ & $9.06 \mathrm{a}$ & $75.66 \mathrm{a}$ & $6.41 \mathrm{a}$ & $10.33 \mathrm{~b}$ & $51.00 \mathrm{a}$ & $12.24 \mathrm{~b}$ & $61 \mathrm{~b}$ \\
\hline SV 06 & $3.50 \mathrm{~b}$ & $10.45 \mathrm{a}$ & $88.49 \mathrm{~b}$ & $8.16 \mathrm{~b}$ & $9.66 \mathrm{a}$ & $47.83 \mathrm{a}$ & $10.44 \mathrm{~b}$ & $68 \mathrm{e}$ \\
\hline SV 07 & $3.26 \mathrm{a}$ & $18.84 \mathrm{~b}$ & $77.99 \mathrm{a}$ & $7.49 b$ & $10.99 \mathrm{~b}$ & $44.25 \mathrm{a}$ & $8.88 \mathrm{a}$ & $65 \mathrm{~d}$ \\
\hline SV 08 & $4.06 \mathrm{c}$ & $10.47 \mathrm{a}$ & $85.83 \mathrm{~b}$ & $6.95 b$ & $9.66 \mathrm{a}$ & $51.49 \mathrm{a}$ & $10.98 \mathrm{~b}$ & $65 \mathrm{~d}$ \\
\hline SV 09 & $4.09 \mathrm{c}$ & $9.29 \mathrm{a}$ & $76.50 \mathrm{a}$ & $6.66 \mathrm{a}$ & $10.00 \mathrm{a}$ & $45.99 \mathrm{a}$ & $8.49 \mathrm{a}$ & $63 \mathrm{c}$ \\
\hline SV 10 & $4.13 \mathrm{c}$ & $8.04 \mathrm{a}$ & $73.33 \mathrm{a}$ & $6.66 \mathrm{a}$ & $10.16 \mathrm{a}$ & $47.83 \mathrm{a}$ & $9.10 \mathrm{a}$ & $61 \mathrm{~b}$ \\
\hline SV 11 & $3.58 \mathrm{~b}$ & $19.58 \mathrm{~b}$ & $84.49 \mathrm{~b}$ & $7.33 b$ & $11.00 \mathrm{~b}$ & $48.24 \mathrm{a}$ & $8.83 \mathrm{a}$ & $68 \mathrm{e}$ \\
\hline SV 12 & $3.45 \mathrm{~b}$ & $10.00 \mathrm{a}$ & $86.91 \mathrm{~b}$ & $7.16 \mathrm{~b}$ & $10.83 \mathrm{~b}$ & $48.91 \mathrm{a}$ & $10.36 \mathrm{~b}$ & $68 \mathrm{e}$ \\
\hline SV 13 & $3.88 \mathrm{c}$ & $20.70 \mathrm{~b}$ & $77.16 \mathrm{a}$ & $7.33 b$ & $10.16 \mathrm{a}$ & $52.41 \mathrm{a}$ & $10.68 \mathrm{~b}$ & $68 \mathrm{e}$ \\
\hline SV 14 & $3.99 \mathrm{c}$ & $10.31 \mathrm{a}$ & $85.83 \mathrm{~b}$ & $7.49 b$ & $11.16 \mathrm{~b}$ & $44.08 \mathrm{a}$ & $9.35 \mathrm{a}$ & $65 \mathrm{~d}$ \\
\hline SV 15 & $4.03 \mathrm{c}$ & $8.80 \mathrm{a}$ & $75.00 \mathrm{a}$ & $6.79 \mathrm{a}$ & $10.66 \mathrm{~b}$ & $47.83 \mathrm{a}$ & $10.63 \mathrm{~b}$ & $65 \mathrm{~d}$ \\
\hline SV 16 & $3.19 \mathrm{a}$ & $8.89 \mathrm{a}$ & $80.66 \mathrm{~b}$ & $7.75 b$ & $11.33 \mathrm{~b}$ & $36.49 \mathrm{a}$ & $10.10 \mathrm{~b}$ & $68 \mathrm{e}$ \\
\hline SV 17 & $3.86 \mathrm{c}$ & $9.10 \mathrm{a}$ & $84.16 b$ & $7.50 \mathrm{~b}$ & $10.16 \mathrm{a}$ & $49.41 \mathrm{a}$ & $10.88 \mathrm{~b}$ & $65 \mathrm{~d}$ \\
\hline SV 18 & $4.06 \mathrm{c}$ & $9.23 \mathrm{a}$ & $77.00 \mathrm{a}$ & $7.17 b$ & $10.50 \mathrm{~b}$ & $49.16 \mathrm{a}$ & $9.33 \mathrm{a}$ & $61 \mathrm{~b}$ \\
\hline SV 19 & $4.28 \mathrm{c}$ & $9.61 \mathrm{a}$ & $81.66 \mathrm{~b}$ & $7.16 \mathrm{~b}$ & $10.00 \mathrm{a}$ & $48.33 \mathrm{a}$ & $9.71 \mathrm{a}$ & $65 \mathrm{~d}$ \\
\hline SV 20 & $3.91 \mathrm{c}$ & $9.41 \mathrm{a}$ & $85.83 \mathrm{~b}$ & $7.83 \mathrm{~b}$ & $10.50 \mathrm{~b}$ & $50.08 \mathrm{a}$ & $9.85 \mathrm{~b}$ & $68 \mathrm{e}$ \\
\hline SV 21 & $4.21 \mathrm{c}$ & $9.24 \mathrm{a}$ & $79.08 \mathrm{~b}$ & $7.60 \mathrm{~b}$ & $10.00 \mathrm{a}$ & $54.41 \mathrm{a}$ & $9.36 \mathrm{a}$ & $68 \mathrm{e}$ \\
\hline SV 22 & $4.18 \mathrm{c}$ & $9.74 \mathrm{a}$ & $66.91 \mathrm{a}$ & $5.96 \mathrm{a}$ & $11.50 \mathrm{~b}$ & $52.75 \mathrm{a}$ & $12.62 \mathrm{~b}$ & $65 \mathrm{~d}$ \\
\hline SV 23 & $3.97 \mathrm{c}$ & $9.52 \mathrm{a}$ & $78.00 \mathrm{a}$ & $7.67 \mathrm{~b}$ & $10.17 \mathrm{a}$ & $49.00 \mathrm{a}$ & $7.83 \mathrm{a}$ & $65 \mathrm{~d}$ \\
\hline SV 24 & $4.41 \mathrm{c}$ & $10.37 \mathrm{a}$ & $78.58 \mathrm{~b}$ & $6.92 \mathrm{~b}$ & $10.83 \mathrm{~b}$ & $53.33 \mathrm{a}$ & $12.56 \mathrm{~b}$ & $63 \mathrm{c}$ \\
\hline SV 25 & $3.74 \mathrm{~b}$ & $8.96 \mathrm{a}$ & $79.33 \mathrm{~b}$ & $7.81 \mathrm{~b}$ & $9.66 \mathrm{a}$ & $49.75 \mathrm{a}$ & $8.70 \mathrm{a}$ & $65 \mathrm{~d}$ \\
\hline SV 26 & $4.16 \mathrm{c}$ & $8.82 \mathrm{a}$ & $75.66 \mathrm{a}$ & $7.16 \mathrm{~b}$ & $10.66 \mathrm{~b}$ & $52.16 \mathrm{a}$ & $10.05 \mathrm{~b}$ & $65 \mathrm{~d}$ \\
\hline SV 27 & $4.15 \mathrm{c}$ & $9.03 \mathrm{a}$ & $75.50 \mathrm{a}$ & $6.81 \mathrm{a}$ & $9.67 \mathrm{a}$ & $42.00 \mathrm{a}$ & $7.94 \mathrm{a}$ & $65 \mathrm{~d}$ \\
\hline SV 28 & $4.12 \mathrm{c}$ & $9.22 \mathrm{a}$ & $70.41 \mathrm{a}$ & $6.59 \mathrm{a}$ & $10.83 \mathrm{~b}$ & $50.25 \mathrm{a}$ & $10.34 \mathrm{~b}$ & $65 \mathrm{~d}$ \\
\hline SV 29 & $4.10 \mathrm{c}$ & $9.30 \mathrm{a}$ & $76.16 \mathrm{a}$ & $6.61 \mathrm{a}$ & $9.50 \mathrm{a}$ & $53.33 \mathrm{a}$ & $8.64 \mathrm{a}$ & $63 \mathrm{c}$ \\
\hline SV 30 & $4.10 \mathrm{c}$ & $8.82 \mathrm{a}$ & $76.50 \mathrm{a}$ & $6.33 \mathrm{a}$ & $10.33 \mathrm{~b}$ & $49.00 \mathrm{a}$ & $11.15 \mathrm{~b}$ & $61 \mathrm{~b}$ \\
\hline SV 31 & $4.23 \mathrm{c}$ & $10.00 \mathrm{a}$ & $83.75 \mathrm{~b}$ & $7.26 \mathrm{~b}$ & $9.50 \mathrm{a}$ & $49.83 \mathrm{a}$ & $10.27 \mathrm{~b}$ & $65 \mathrm{~d}$ \\
\hline SV 32 & $3.64 \mathrm{~b}$ & $9.47 \mathrm{a}$ & $82.83 \mathrm{~b}$ & $6.91 \mathrm{~b}$ & $10.00 \mathrm{a}$ & $48.50 \mathrm{a}$ & $9.55 \mathrm{a}$ & $65 \mathrm{~d}$ \\
\hline SV 33 & $4.17 \mathrm{c}$ & $9.45 \mathrm{a}$ & $83.33 \mathrm{~b}$ & $7.21 \mathrm{~b}$ & $10.00 \mathrm{a}$ & $50.17 \mathrm{a}$ & $10.02 \mathrm{~b}$ & $65 \mathrm{~d}$ \\
\hline SV 34 & $3.72 \mathrm{~b}$ & $5.81 \mathrm{a}$ & $82.00 \mathrm{~b}$ & $6.50 \mathrm{a}$ & $10.50 \mathrm{~b}$ & $54.95 \mathrm{a}$ & $11.41 \mathrm{~b}$ & $65 \mathrm{~d}$ \\
\hline SV 35 & $3.57 \mathrm{~b}$ & $8.69 \mathrm{a}$ & $79.15 b$ & $7.00 \mathrm{~b}$ & $10.33 \mathrm{~b}$ & $43.00 \mathrm{a}$ & $7.91 \mathrm{a}$ & $65 \mathrm{~d}$ \\
\hline SV 36 & $3.63 \mathrm{~b}$ & $9.19 \mathrm{a}$ & $81.66 \mathrm{~b}$ & $6.58 \mathrm{a}$ & $10.83 \mathrm{~b}$ & $50.50 \mathrm{a}$ & $9.81 \mathrm{~b}$ & $65 \mathrm{~d}$ \\
\hline SV 37 & $4.02 \mathrm{c}$ & $8.27 \mathrm{a}$ & $71.25 \mathrm{a}$ & $5.50 \mathrm{a}$ & $10.17 \mathrm{a}$ & $47.17 \mathrm{a}$ & $8.74 \mathrm{a}$ & $61 \mathrm{~b}$ \\
\hline SV 38 & $3.79 \mathrm{~b}$ & $8.96 \mathrm{a}$ & $85.33 \mathrm{~b}$ & $7.50 \mathrm{~b}$ & $10.00 \mathrm{a}$ & $46.00 \mathrm{a}$ & $8.73 \mathrm{a}$ & $63 \mathrm{c}$ \\
\hline
\end{tabular}


Table 2 (continuation). Means of quantitative traits evaluated in broom sorghum accessions and Scott-Knott Test per variable.

\begin{tabular}{|c|c|c|c|c|c|c|c|c|}
\hline SV 39 & $4.03 \mathrm{c}$ & $8.45 \mathrm{a}$ & $80.67 \mathrm{~b}$ & $7.00 \mathrm{~b}$ & $10.16 \mathrm{a}$ & $49.16 \mathrm{a}$ & $7.88 \mathrm{a}$ & $65 \mathrm{~d}$ \\
\hline SV 40 & $3.75 \mathrm{~b}$ & $9.36 \mathrm{a}$ & $78.66 \mathrm{~b}$ & $6.85 \mathrm{a}$ & $10.50 \mathrm{~b}$ & $52.08 \mathrm{a}$ & $10.83 \mathrm{~b}$ & $61 \mathrm{~b}$ \\
\hline SV 41 & $4.04 \mathrm{c}$ & $8.78 \mathrm{a}$ & $75.66 \mathrm{a}$ & $7.00 \mathrm{~b}$ & $9.83 \mathrm{a}$ & $53.50 \mathrm{a}$ & $9.08 \mathrm{a}$ & $61 \mathrm{~b}$ \\
\hline SV 42 & $3.96 \mathrm{c}$ & $8.15 \mathrm{a}$ & $77.00 \mathrm{a}$ & $5.95 \mathrm{a}$ & $10.33 \mathrm{~b}$ & $50.15 \mathrm{a}$ & $10.75 \mathrm{~b}$ & $58 \mathrm{a}$ \\
\hline SV 43 & $3.87 \mathrm{c}$ & $8.58 \mathrm{a}$ & $73.00 \mathrm{a}$ & $5.83 \mathrm{a}$ & $10.16 \mathrm{a}$ & $49.16 \mathrm{a}$ & $8.83 \mathrm{a}$ & $61 \mathrm{~b}$ \\
\hline SV 44 & $4.15 \mathrm{c}$ & $9.33 \mathrm{a}$ & $70.83 \mathrm{a}$ & $6.13 \mathrm{a}$ & $10.00 \mathrm{a}$ & $47.15 \mathrm{a}$ & $10.61 \mathrm{~b}$ & $63 \mathrm{c}$ \\
\hline SV 45 & $4.10 \mathrm{c}$ & $8.59 \mathrm{a}$ & $74.00 \mathrm{a}$ & $5.50 \mathrm{a}$ & $10.16 \mathrm{a}$ & $49.83 \mathrm{a}$ & $10.40 \mathrm{~b}$ & $61 \mathrm{~b}$ \\
\hline SV 46 & $4.08 \mathrm{c}$ & $10.06 \mathrm{a}$ & $70.83 \mathrm{a}$ & $6.16 \mathrm{a}$ & $10.50 \mathrm{~b}$ & $52.33 \mathrm{a}$ & $8.36 \mathrm{a}$ & $61 \mathrm{~b}$ \\
\hline SV 47 & $4.00 \mathrm{c}$ & $9.08 \mathrm{a}$ & $66.37 \mathrm{a}$ & $6.30 \mathrm{a}$ & $10.50 \mathrm{~b}$ & $47.73 \mathrm{a}$ & $10.50 \mathrm{~b}$ & $61 \mathrm{~b}$ \\
\hline SV 48 & $4.05 \mathrm{c}$ & $8.58 \mathrm{a}$ & $71.35 \mathrm{a}$ & $7.85 \mathrm{~b}$ & $10.16 \mathrm{a}$ & $52.00 \mathrm{a}$ & $9.40 \mathrm{a}$ & $61 \mathrm{~b}$ \\
\hline SV 49 & $4.09 \mathrm{c}$ & $9.84 \mathrm{a}$ & $75.15 \mathrm{a}$ & $7.55 \mathrm{~b}$ & $9.66 \mathrm{a}$ & $52.15 \mathrm{a}$ & $8.75 \mathrm{a}$ & $61 \mathrm{~b}$ \\
\hline SV 50 & $3.95 \mathrm{c}$ & $7.53 \mathrm{a}$ & $73.33 \mathrm{a}$ & $6.00 \mathrm{a}$ & $9.85 \mathrm{a}$ & $48.35 \mathrm{a}$ & $7.94 \mathrm{a}$ & $61 \mathrm{~b}$ \\
\hline SV 51 & $3.79 \mathrm{~b}$ & $8.37 \mathrm{a}$ & $83.75 \mathrm{~b}$ & $6.28 \mathrm{a}$ & $10.00 \mathrm{a}$ & $48.85 \mathrm{a}$ & $10.75 \mathrm{~b}$ & $61 \mathrm{~b}$ \\
\hline SV 52 & $4.08 \mathrm{c}$ & $9.36 \mathrm{a}$ & $70.48 \mathrm{a}$ & $6.83 \mathrm{a}$ & $10.00 \mathrm{a}$ & $54.16 \mathrm{a}$ & $10.03 \mathrm{~b}$ & $65 \mathrm{~d}$ \\
\hline SV 53 & $3.86 \mathrm{c}$ & $8.94 \mathrm{a}$ & $81.83 \mathrm{~b}$ & $7.59 \mathrm{~b}$ & $10.83 \mathrm{~b}$ & $54.00 \mathrm{a}$ & $8.96 \mathrm{a}$ & $61 \mathrm{~b}$ \\
\hline SV 54 & $4.12 \mathrm{c}$ & $8.90 \mathrm{a}$ & $76.56 \mathrm{a}$ & $6.32 \mathrm{a}$ & $10.67 \mathrm{~b}$ & $48.58 \mathrm{a}$ & $9.91 \mathrm{~b}$ & $61 \mathrm{~b}$ \\
\hline SV 55 & $4.02 \mathrm{c}$ & $8.40 \mathrm{a}$ & $74.33 \mathrm{a}$ & $6.33 \mathrm{a}$ & $9.83 \mathrm{a}$ & $52.50 \mathrm{a}$ & $9.52 \mathrm{a}$ & $61 \mathrm{~b}$ \\
\hline SV 56 & $3.77 \mathrm{~b}$ & $8.80 \mathrm{a}$ & $84.80 \mathrm{~b}$ & $6.80 \mathrm{a}$ & $9.83 \mathrm{a}$ & $49.15 \mathrm{a}$ & $8.72 \mathrm{a}$ & $61 \mathrm{~b}$ \\
\hline SV 57 & $4.22 \mathrm{c}$ & $9.48 \mathrm{a}$ & $81.13 \mathrm{~b}$ & $7.83 \mathrm{~b}$ & $11.00 \mathrm{~b}$ & $55.00 \mathrm{a}$ & $10.50 \mathrm{~b}$ & $63 \mathrm{c}$ \\
\hline SV 58 & $4.13 \mathrm{c}$ & $9.47 \mathrm{a}$ & $70.48 \mathrm{a}$ & $7.67 \mathrm{~b}$ & $10.16 \mathrm{a}$ & $57.83 \mathrm{a}$ & $11.25 \mathrm{~b}$ & $61 \mathrm{~b}$ \\
\hline SV 59 & $4.05 \mathrm{c}$ & $9.32 \mathrm{a}$ & $77.65 \mathrm{a}$ & $5.88 \mathrm{a}$ & $9.33 \mathrm{a}$ & $50.05 \mathrm{a}$ & $8.18 \mathrm{a}$ & $63 \mathrm{c}$ \\
\hline SV 60 & $4.34 \mathrm{c}$ & $9.82 \mathrm{a}$ & $72.83 \mathrm{a}$ & $6.90 \mathrm{~b}$ & $8.83 \mathrm{a}$ & $60.50 \mathrm{a}$ & $12.41 \mathrm{~b}$ & $61 \mathrm{~b}$ \\
\hline SV 61 & $3.75 \mathrm{~b}$ & $8.66 \mathrm{a}$ & $70.08 \mathrm{a}$ & $6.72 \mathrm{a}$ & $9.98 \mathrm{a}$ & $51.58 \mathrm{a}$ & $8.58 \mathrm{a}$ & $61 \mathrm{~b}$ \\
\hline SV 62 & $3.78 \mathrm{~b}$ & $9.06 \mathrm{a}$ & $86.35 \mathrm{~b}$ & $8.16 \mathrm{~b}$ & $9.98 \mathrm{a}$ & $55.50 \mathrm{a}$ & $11.71 \mathrm{~b}$ & $61 \mathrm{~b}$ \\
\hline SV 63 & $3.73 \mathrm{~b}$ & $8.51 \mathrm{a}$ & $79.66 \mathrm{~b}$ & $5.55 \mathrm{a}$ & $10.30 \mathrm{~b}$ & $53.33 \mathrm{a}$ & $10.30 \mathrm{~b}$ & $61 \mathrm{~b}$ \\
\hline SV 64 & $3.73 \mathrm{~b}$ & $7.38 \mathrm{a}$ & $72.66 \mathrm{a}$ & $6.33 \mathrm{a}$ & $9.33 \mathrm{a}$ & $48.50 \mathrm{a}$ & $9.21 \mathrm{a}$ & $61 \mathrm{~b}$ \\
\hline SV 65 & $3.73 \mathrm{~b}$ & $9.56 \mathrm{a}$ & $80.50 \mathrm{~b}$ & $7.16 \mathrm{~b}$ & $9.50 \mathrm{a}$ & $52.50 \mathrm{a}$ & $10.85 \mathrm{~b}$ & $58 \mathrm{a}$ \\
\hline SV 66 & $3.74 \mathrm{~b}$ & $10.03 \mathrm{a}$ & $69.50 \mathrm{a}$ & $6.76 \mathrm{a}$ & $10.15 \mathrm{a}$ & $44.15 \mathrm{a}$ & $9.90 \mathrm{~b}$ & $58 \mathrm{a}$ \\
\hline
\end{tabular}

Means followed by the same letter in each column do not differ among one another, according to Scott-Knott Test $(\mathrm{P}<0.01)$. Plant height $(\mathrm{PH})$; stem diameter $(\mathrm{SD})$; length of third leaf blade (LLB); width of third leaf blade (WLB); number of leaves (NL); panicle length (PL); length of secondary branching (LSB); number of days from emergence to flowering (NDF).

directly associated with the size and durability of brooms. The panicle length trait did not reveal differences among the accessions, presenting overall mean of $50.15 \mathrm{~cm}$. Thus, the accessions were classified into only one group, as per ScottKnott Test. According to Foltran (2012), the better quality panicle presents the majority of the filaments with similar diameter and panicle length around 50 to $60 \mathrm{~cm}$. It was verified that $50 \%$ of the studied accessions presented panicles within this interval. The same author says that panicles with sizes ranging from 20 to $30 \mathrm{~cm}$ can be used 
as filler material for brooms. In this sense, it can be noted that all evaluated accessions can be used for manufacture of brooms.

The results obtained for this trait contradicts those found by Favarato et al. (2011), who obtained mean value of $40.77 \mathrm{~cm}$ for panicle length, when studying some of these accessions in a similar environment.

Length of secondary branching is another trait that is directly associated with the quality of a good panicle. The accessions presented mean value of $9.82 \mathrm{~cm}$ and differed among one another, according to the test applied. Therefore, two groups were formed, showing that there is variability among the material. In their experiment, Favarato et al. (2011) obtained mean value of $12.61 \mathrm{~cm}$ for LSB, a result that diverges from those observed in this study.

Number of days from emergence to flowering presented five groups, as per ScottKnott Test at $\mathrm{P}<0.01$, thus demonstrating that there is variability among the material. The accessions 42, 65 and 66 were the earliest ones, with mean value of 58 days for flowering.

Studies carried out by Silva et al. (2009) found mean values over 70 days for flowering, when they were assessing different grain sorghum cultivars in the second crop (safrinha) in the southwest region of the state of Goiás. Silva (2016), when evaluating genetic diversity among grain sorghum accessions using morphoagronomic descriptors and molecular markers, observed mean value of 84.1 days for flowering.
Moreover, the accessions 42, 65 and 66 presented earliness, which is a desirable characteristic for improvement programs, since the broom sorghum is grown in small properties by small farmers who need to optimize the land use in order to be able to grow other crops in succession in the same area.

\section{Study of the correlation between the quantitative variables}

The Pearson correlation coefficient measures the degree of association between two traits and this coefficient ranges from -1 to 1 . The sign indicates the positive or negative orientation of the association and the value suggests its magnitude (Figueiredo Filho \& Silva Júnior, 2009). Through a perfect Pearson correlation, the researcher is able to select one trait of complex measurement by means of a trait that is easily measured (Table 3).

According to Cohen (1988), correlations that present values between 0.10 and 0.29 are considered small; correlations between 0.30 and 0.49 can be considered medium; and between 0.50 and 1 are considered large. Differently, Dancey and Reidy (2006) classify the correlations from 0.10 to 0.30 as weak; correlations from 0.40 to 0.60 as moderate; and correlations from 0.70 to 1 as strong.

Through the correlation analysis, it was observed that panicle length and plant height presented correlations significant at $1 \%$ probability as per t-test, thus presenting moderate correlations according to Dancey and Reidy 
Table 3. Estimation of Pearson correlation coefficients, p-value associated with each correlation estimate (beneath the main diagonal) for the quantitative traits.

\begin{tabular}{l|cccccccc}
\hline Traits & PH & SD & LLB & WLB & NL & PL & LSB & NDF \\
\hline PH & - & & & & & & & \\
SD & $-0.19^{\text {ns }}$ & - & & & & & \\
LLB & $-0.38^{* *}$ & $0.12^{\text {ns }}$ & - & & & & \\
WLB & $-0.13^{\text {ns }}$ & $0.27^{* *}$ & $0.47^{* *}$ & - & & & & \\
NL & $-0.13^{\text {ns }}$ & $0.21^{*}$ & $0.01^{\text {ns }}$ & $0.05^{\text {ns }}$ & - & & & \\
PL & $0.35^{* *}$ & $-0.07^{\text {ns }}$ & $-0.08^{\text {ns }}$ & $0.06^{\text {ns }}$ & $-0.31^{* *}$ & - & & \\
LSB & $0.18^{\text {ns }}$ & $-0.00^{\text {ns }}$ & $0.01^{\text {ns }}$ & $0.01^{\text {ns }}$ & $0.13^{\text {ns }}$ & $0.47^{* *}$ & - & \\
NDF & $-0.11^{\text {ns }}$ & $0.38^{* *}$ & $0.40^{* *}$ & $0.43^{* *}$ & $0.28^{* *}$ & $-0.23^{*}$ & $-0.06^{\text {ns }}$ & - \\
\hline
\end{tabular}

PH- plant height; SD- stem diameter; LLB- length of leaf blade; WLB- width of leaf blade; NL- number of leaves; PL- panicle length; LSB- length of secondary branching; NDF- number of days from emergence to flowering. $* * *$ ns: Significant at $1 \%$ and $5 \%$ probability and not significant, respectively, according to t-test.

(2006). The same was observed for number of days for flowering and stem diameter (0.38); leaf blade width and leaf blade length (0.47); leaf blade length and number of days from emergence to flowering (0.40); number of days from emergence to flowering and leaf blade width (0.43); and length of secondary branching and panicle length (0.47).

The correlations between leaf blade width and stem diameter (0.27) and number of days for flowering and number of leaves (0.28) presented correlations significant at $1 \%$ probability as per t-test, though the correlations were weak. The correlation between number of leaves and stem diameter (0.21) presented correlations significant at $5 \%$ probability as per t-test, being considered small, according to Cohen (1988).

\section{Study of accession grouping using quantitative traits}

Through the genetic diversity analysis, using Tocher grouping method, it was possible to identify the differences among accessions, with the formation of five groups (Table 4). This result demonstrates the genetic diversity among the genotypes and the efficacy of the studied characters to describe it. The formation of these groups contributes to the selection of genitors for potential crosses, based on the magnitude of their dissimilarities.

In group I, $41 \%$ of the accessions studied were placed together. These accessions presented intermediate plant height and smaller stem diameter, as well as a number of 65 days for flowering. In regard to group II, $47 \%$ of the accessions were placed together, including those with greater plant height, smaller stem 
Table 4. Formation of groups with 66 broom sorghum accessions, according to the Tocher method, based on the Mahalanobis distance.

\begin{tabular}{|c|c|c|}
\hline Groups & Accessions & $\%$ of Accessions \\
\hline \multirow[t]{2}{*}{ I } & $19,33,31,8,17,1,32,15,26,23,39,25,27,52,28,36,35,14,29,59$, & 41 \\
\hline & $9,44,38,24,57,22,34$ & \\
\hline \multirow[t]{2}{*}{ II } & $37,43,55,42,45,54,30,10,18,41,50,47,61,64,56,40,5,51,4,49$, & 47 \\
\hline & $48,53,46,63,58,62,65,66,3,60,2$ & \\
\hline III & $6,12,20,21,16$ & 7.5 \\
\hline IV & 11,13 & 3 \\
\hline $\mathbf{V}$ & 7 & 1.5 \\
\hline Total & 66 & 100 \\
\hline
\end{tabular}

diameter, and a number of 61days for flowering. Such results corroborate those found by Oliveira (2015), who obtained $68 \%$ of the genotypes in groups I and II, when studying genetic divergence and correlation between characters of sweet sorghum genotypes, in the region of Cáceres, MT.

In group III, five accessions were included, which represents $7.5 \%$ of the total. This group was formed by accessions with intermediate plant height, shorter panicle length, and later flowering (68 days). Group IV was formed by accessions 11 and 13, which present intermediate plant height and greater number of days until flowering. In respect to group $\mathrm{V}$, it was formed only by accession 7 , which presents lower plant height and larger stem diameter.

Taking into consideration that the most important trait of the broom sorghum is the panicle length and that this length must be between 50 and $60 \mathrm{~cm}$, it can be noted that almost all groups present accessions with potential for future launches. The promising accessions are as follows: in group I - 8, 22, 24, 26, 28, 29, 33, 34, 36, 52, 27 and 59; in group II - 4, 5, 40, 41, 48, $49,53,55,58,60,61,62,63$ and 65 ; in group III - 20 and 21; and in group IV - 13.

\section{Conclusions}

Genetic variability was identified among broom sorghum accessions through morphoagronomic analyses. Based on the traits studied, the accessions $2,7,11,13,16,42,65$ and 66 presented desirable traits, thus being more promising for subsequent crosses and studies.

From the 66 accessions studied, 50\% presented panicle length ideal for broom 
manufacture. Based on the groups formed, it was possible to identify the accessions in each group that presented potential for future studies and launches.

\section{Acknowledgments}

To the Coordination for the Improvement of Higher Education Personnel (CAPES) and to the Federal University of Viçosa (UFV) for the support.

\section{References}

BHERING, L. L. Rbio: a tool for biometric and statistical analysis using the $\mathrm{R}$ platform. Crop Breeding and Applied Biotechnology, v. 17 , n. 2, p. 187-190, 2017. DOI: 10.1590/1984-70332017v17n2s29.

COHEN, J. Statistical power analysis for the behavioral sciences. 2. ed. Hillsdale: Routledge, 1988.

CRUZ, C. D. Programa genes: aplicativo computacional em genética e estatística. Viçosa, MG: Universidade Federal de Viçosa, 2017.

DANCEY, C.; REIDY, J. Estatística sem matemática para psicologia: usando SPSS para Windows. Porto Alegre: Artmed, 2006.

FARIAS, G. A. A. M.; FARIAS, J. G.; NORONHA, J. F. Rentabilidade da produção de vassoura de sorgo-vassoura (Sorghum bicolor (L.) Moench). Pesquisa Agropecuária Tropical, v. 30, n. 1, p. 97-102, 2000.

FAVARATO, L. F.; PAULA, G. S.; ESPINDULA,
M. C.; ROCHA, V. S. Avaliação de linhagens de sorgo vassoura na região de Viçosa, $\mathrm{MG}$, Brasil. Revista Brasileira de Milho e Sorgo, v. 10, n. 1, p. 82-86, 2011. DOI: 10.18512/19806477/rbms.v10n1p82-86.

FERREIRA, L. E.; SILVA, I. F.; SOUZA, E. P.; SOUZA, M. A.; BORCHARTT, L. Caracterização física de variedades de sorgo submetidas a diferentes adubações em condição de sequeiro. Revista Verde, v. 7, n. 1, p. 249-255, jan./mar. 2012.

FERREIRA, P. V. Estatística experimental aplicada às ciências agrárias. Viçosa, MG: Universidade Federal de Viçosa, 2018.

FIGUEIREDO FILHO, D. B.; SILVA JÚNIOR, J. A. Desvendando os mistérios do coeficiente de correlação de Pearson (r). Revista Política Hoje, v. 18, n. 1, p. 115-146, 2009.

FOLTRAN, D. E. O sorgo-vassoura como alternativa agrícola regional. Pesquisa e Tecnologia, v. 9, n. 1, p. 1-5, jan./jun. 2012.

FOLTRAN, D. E.; SAWAZAKI, E.; FREITAS, R. S. Novos cultivares de sorgo-vassoura para agricultura regional. Pesquisa e Tecnologia, v. 13, n. 1, p. 1-6, jan./jun. 2016.

FOLTRAN, D. E.; TAVARES, S. Influência da origem da semente, espaçamento e época de plantio na produção e qualidade de palha de sorgo-vassoura. Agropecuária Catarinense, v. 29, n. 3, p. 42-44, set./dez. 2016.

GOMES, F. P. Curso de estatística experimental. Piracicaba: FEALQ, 2009. 451 p.

MAY, A.; SILVA, D. D. da; SANTOS, F. C. dos. Cultivo do sorgo biomassa para a cogeração 
de energia elétrica. Sete Lagoas: Embrapa Milho e Sorgo, 2013. 65 p. (Embrapa Milho e Sorgo. Documentos, 152).

OLIVEIRA, T. C. Divergência genética e correlação entre caracteres de genótipos de sorgo sacarino na região de Cáceres - MT. 2015. 89 f. Dissertação (Mestrado em Genética e Melhoramento de Plantas) - Universidade do Estado do Mato Grosso, Cáceres, 2015.

PERAZZO, A. F.; SANTOS, E. M.; PINHO, R. M. A.; CAMPUS, F. S.; RAMOS, J. P. F.; AQUINO, M. M.; SILVA, T. C.; BEZERRA, H. F. C. Características agronômicas e eficiência do uso da chuva em cultivares de sorgo no semiárido. Ciência Rural, v. 43, n. 10, p. 1771-1776, out. 2013. DOI: $10.1590 / \mathrm{S} 0103-84782013001000007$.

RABELO, F. H. S.; RABELO, C. H. S.; DUPAS, E.; NOGUEIRA, D. A.; REZENDE, A. V. Parâmetros agronômicos do sorgo em razão de estratégias de semeadura e adubação. Pesquisa Aplicada \& Agrotecnologia, v. 5, n. 1, p. 47-66, 2012.
RIBAS, P. Importância econômica. In: RODRIGUES, J. A. S. (Ed.). Cultivo do sorgo. 4. ed. Sete Lagoas: Embrapa Milho e Sorgo, 2008. (Embrapa Milho e Sorgo. Sistemas de Produção, 2). Available in: $<$ http://www.cnpms. embrapa.br/publicacoes/sorgo $>$. Access in: 6 out. 2009.

SILVA, A. G.; BARROS, A. S.; SILVA, L. H. C. P.; MORAES, E. B.; PIRES, R.; TEIXEIRA, I. R. Avaliação de cultivares de sorgo granífero na safrinha no sudoeste do estado de Goiás. Pesquisa Agropecuária Tropical, v. 39, n. 2, p. 168-174, 2009.

SILVA, K. J. da. Diversidade genética entre linhagens de sorgo granífero utilizando descritores morfoagronômicos e marcadores moleculares. 2016. 46 f. Dissertação (Mestrado em Genética e Melhoramento) - Universidade Federal de Viçosa, Viçosa, MG, 2016.

TARDIN, F. D.; ALMEIDA FILHO, J. E.; OLIVEIRA, C. M.; LEITE, C. E. P.; MENEZES, C. B.; MAGALHÃES, P. C.; RODRIGUES, J. A. S.; SCHAFFERT, R. E. Avaliação agronômica de híbridos de sorgo granífero cultivados sob irrigação e estresse hídrico. Revista Brasileira de Milho e Sorgo, v. 12, n. 2, p. 102117, 2013. DOI: 10.18512/1980-6477/rbms. v12n2p102-117. 